\title{
Transverse architecture of the Moine Thrust Belt and Moine Nappe, Northern Highlands, Scotland: new insight on a classic thrust belt
}

A.G. Leslie $(*)$ \& M. Krabbendam $(*)$

ABSTRACT

The Caledonian Moine Thrust belt is a world class example of a forelan propagating fold-and-thrust belt. The late $19^{\text {th }}$ and early $20^{\text {th }}$ century research in this region was seminal in thrust tectonics, alongside contemporaneous studies of the Alps and Apennines. New British Geological Survey syntheses of the Assyn and Ullapool regions of the Moine Thrust Belt recognise previously mappreciated transverse Zone which accommodate sharp lateral ch structural architecture of the brittle-ductile thrust belt, and of the ductile thrus nappes to the east of the Moine Thrust. The Traligill Transverse zones transects the classic Assynt Culmination; the Oykel Tranverse Zone constrains the southern boundary of the Cassley Culmination in Moine rocks east of Assynt. Both transverse structures are oriented sub-parallel to the thrust transpor direction and are related to pre-existing faults involving basement.

KeY wORDS: Thrust systems, Transverse Zones, Culminations, Moine Thrust Belt, Northern Highlands.

\section{RIASSUNTO}

Evoluzione strutturale di una successione di avanfossa: l'Unità Dauna nel settore molisano-sannita dell'Appennino meridionale.

La catena caledoniana del Moine Thrust nelle Highlands settentrionali della Scozia è uno splendido esempio di sistema orogenico propagatosi verso l'ozia è uno splendido esempio di sistema orogenico propagatosi verso

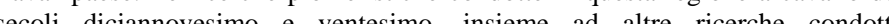
indipendentemente nello stesso periodo fra le Alpi e l'A pennino, sono state un preziona f'informazione ed hanno contribuito a gettare le basi della una tectonics. Le sintesi sull'aggiornanto delle regioni di Assynt e di Ullapool nella Ca. Le sinel Moine Thrust, realizzate da parte del British Geological Survey, ella Catena del Moine Thrust, realizzate da parte del British Geological Survey, hanno condotto all individuazione di lineamenti trasversali fino ad oggi no importanti variazioni laterali nell'architettura fragile-duttile della catena a pieghe e sovrascorrimenti, e delle falde di ricoprimento con carattere deformativi duttile e sovrascorrimenti, e delle falde di ricoprimento con carattere deformativi duttile presenti ad est del Sovrascorrimento di Moine. Il Lineamento Trasversale di Traligill interrompe la continuità laterale della classica Culminazione di Assynt; Culminazione di Cassley nelle rocce del Gruppo di Moine ad est di Assynt. Culminazione di Cassley nelle rocce del Gruppo di Moine ad est di Assynt. tettonico: si tratta essenzialmente di lineamenti che interessano anche il basamento, lungo i quali si sono verificati processi di riattivazione di faglie preorogeniche.

TERMini CHIAVE: Sistemi di sovrascorrimenti, Lineament trasversali, Culminazioni, Catena del Moine Thrust, Highlands settentrionali.

*) British Geological Survey, Murchison House, West Mains Road, Edinburgh, EH9 3LA. E-mail: agle@bgs.ac.uk.

The geometry, kinematics, mechanics and petroleum potential of fold-andthrust belts are intensely studied worldwide (McClay 1992, 2004 and references therein). Palinspastic reconstructions and balanced cross-sections parallel to the thrust transport direction are common; far fewer examine how lateral variations in thrust architecture are linked via so-called transverse zones that might for example comprise lateral culmination walls, strike-slip faults, or lateral ramps (e.g. Laubscher, 1985; Mitra, 1988; Paulsen \& MarshaK, 1988, 1999; Thomas, 1990; Fermor, 1999; Bégin \& Spratt, 2002; Butler et alii, 2006; TaVARnell et alii, 2004). Like these Alpine, Apennine, Appalachian and Rocky Mountain examples, the Moine Thrust Belt displays a high degree of lateral continuity. Significant lateral variation has been reported, though related to development of duplexes and associated culmination structures (e.g. ЕLLIOTT \& JoHNSon, 1980; BUTLER et alii, 2007). Now, fully a century after publication of the classic Northwest Highlands memoir (РеАсн et alii, 1907), new detailed mapping and structural analysis in the Moine Thrust belt (MTB) by the British Geological Survey (BGS) highlights previously unappreciated abrupt north-south lateral variations in both thrust architecture, and in the internal configuration of individual thrus sheets and culminations. New maps in the thrust belt have been published (Assynt, BGS 2007; Ullapool, BGS 2008) and further new maps of the Moine rocks in the hanging wall of the MTB are in an advanced state for publication (BGS in press, a \& b). Here we briefly report upon examples of brittle-ductile and ductile transverse zones identified in the MTB and the internal orogen respectively (see also KrabBendam \& LesLie in press, 2009; LesLIE et alii, in press, 2009).

A crustal-scale WNW-vergent fold-and-thrust-belt system is preserved in the Northern Highlands of Scotland, generated by Baltica-Laurentia plate collision during the Scandian (Silurian) phase of the Caledonian Orogeny. The MTB marks the northwestern margin of that system and is a world class example of thrust geometry and tectonics (fig 1). The Moine Thrust defines the roof of the MTB, and the base of the Moine Nappe sensu lato (British Geological Survey 1997, 2002); as such it is regarded as a convenient boundary in northern Scotland between the external and internal parts of the Caledonian Orogen (fig. 1).

\section{CLASSICAL ASSYNT AND THE OYKEL BRIDGE MULLIONS}

The Moine Thrust Belt has been studied for over 150 years, largely because it contains a great variety of well 
Fig. 1 -Geological map of the Northern Highlands and the Moine Thrust Belt, after British Geological Survey original. Inset shows the location in Scotland. Important

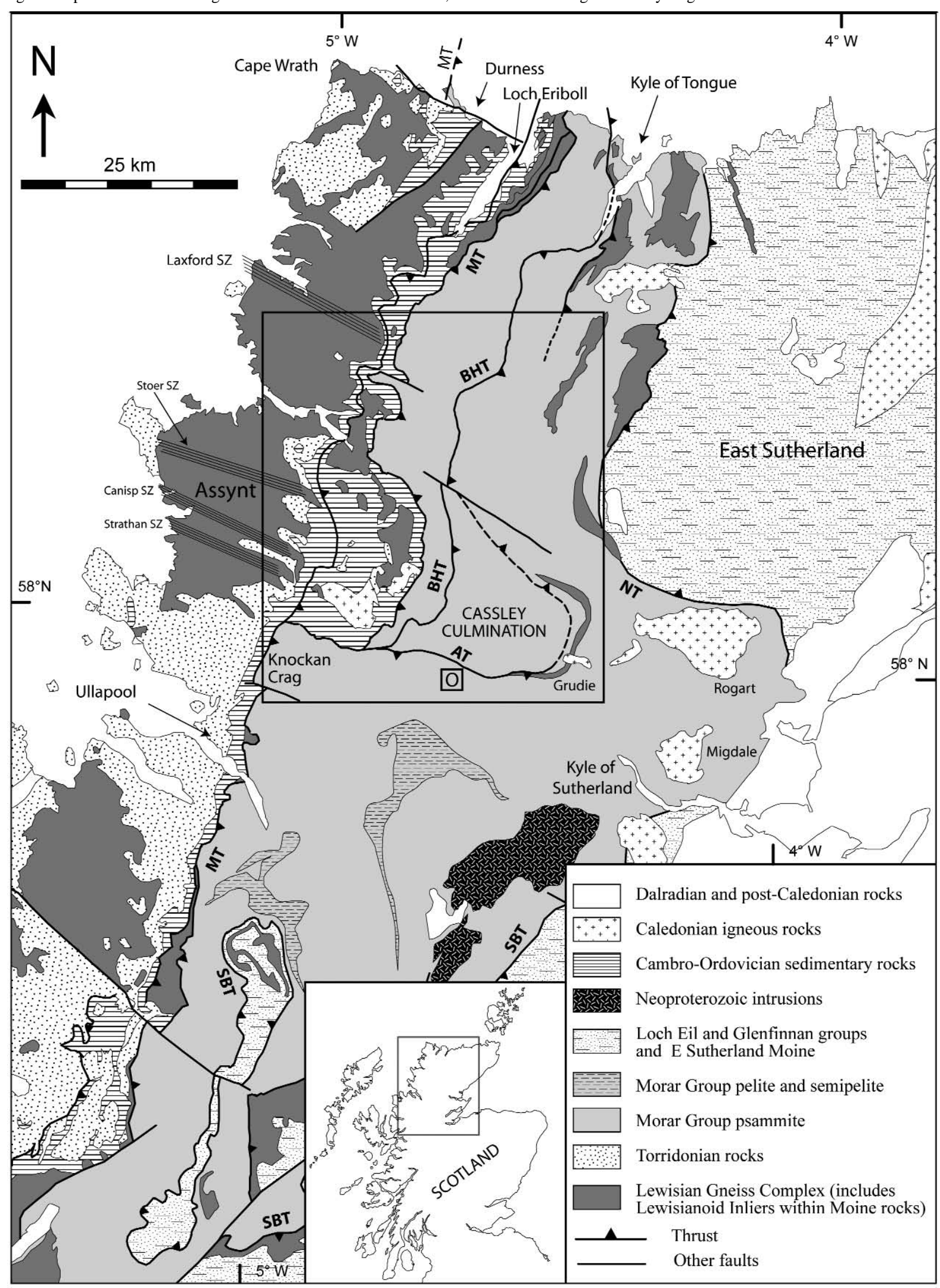

WNW-ESE striking Palaeoproterozoic shear zones are highlighted in the Assynt region. Abbreviations: AT = Achness Thrust; $\mathrm{BHT}=$ Ben Hope Thrust; MT = Moine Thrust; NT = Naver Thrust; $\mathrm{O}=$ Oykel Bridge; SBT = Sgurr Beag Thrust. Box on main map outlines fig. 5a

- Carta Geologica delle Highlands Settentrionali e della Catena del Moine Thrust (dai tipi originalle del Brit riquadro. Sono evidenziate prominenti zone di taglio paleoproterozoiche ad andamento WNW-ESE presenti nella regione di Assynt. Simboli: AT = Achness Thrust;
$B H T=$ Ben Hope Thrust; $M T=$ Moine Thrust; NT = Naver Thrust; $O=$ Oykel Bridge; SBT = Sgurr Beag Thrust. La casella sulla carta principale indica la localizzazione dell'area rappresentata in fig. $5 a$. 
exposed thrust geometries. The late 19th century discoveries of the pioneering geologists working in the Northern Highlands of Scotland, and of their equally pioneering contemporaries working in the Alps and in the Apennines, provided the empirical basis for the recognition of huge sub-horizontal shearing movements in the Earth's crust and their role in mountain formation. In his seminal work in the Northwest Highlands, Professor Charles Lapworth drew inspiration from the Alpine experience of Arnold Escher and Albert Heim in his attack (1882-83) upon the structure of the Eriboll region of the Moine Thrust Zone, especially the graphic and beautifully illustrated accounts of the structures of the Swiss Apennines and Carpathian Mountains (1846-47), Sir Roderick Impey Murchison, though never accepting the validity of a major thrust disrupting strata in the Northern Highlands of Scotland found, when visiting the Canton of Glarus with Escher, that it was «neccessary to admit, that the strata had been inverted..... in one enormous overthrow». Murchison was further impressed in numerous traverses of the Apennines and, «even without quitting the environs of Rome», of the importance of folding and faulting (thrusts) in disrupting the apparen continuity of the successions encountered on his travels with the «men of science of Italy» (MURCHISON, 1849).

Publication of the Реасн et alii, 1907 memoir on 'The Geological Structure of the North-West Highlands of Scotland' saw the climax of the 'Highlands Controversy', sixty years of intense, and at times acrimonious, study and scientific debate. The debate drew heavily upon the new theories of mountain building emerging from Continental Europe and Scotland and helped to shape ground-breaking efforts of a veritable geological united nations at that time. Reputations were made, and broken, in the NW Highlands of Scotland; the mid- to late 19 century scientific discourse and the principal players are brought to life by OLDRoyd (1990). Murchison and Lapworth, Professor James Nicol, geologists Charles Callaway, Ben Peach and John Horne and Director of the Geological Survey Sir Archibald Geiki all examined, and contested, interpretations of how it was that nonfossiliferous metamorphosed rocks (Moine psammites) could overlie fossiiferous sedimentary strata (Durness 'limestone') on apparently concordan boundaries.

The 'Highlands Controversy' was intellectually solved by Charles Lapworth $(1883,1884)$ on the key outcrops near Loch Eriboll (fig. 1), in the northern part of the Moine Thrust Belt. Archibald Geikie, previously Murchison devotee, had by now superseded Murchison as Director of the Geological Survey and sent a team of surveyors to the NW Highlands, led by Benjamin Peach and John Horne. They were to settle the issue once and for all. Charles Lapworth quickly convinced Peach and Horne of the validity and elegance of his solution involving low-angle fault repetitions and so began period of hugely productive geological mapping. Peach, Horne and colleagues gradually worked their way south from Loch Eriboll along the entire thrust belt, producing exquisite geological maps along the way. That superb effort culminated with publication of the classic Geological Survey memoir (РеАсн et alii, 1907) and of the 'Assynt Special Sheet' (Geological Survey of Great Britain, 1923).

East of the MTB, the structure of the central part of the Moine outcrop in Sutherland received little or no

Fig. 2 -Mullion structures in Altnaharra Formation (Morar Group) psammitic rocks of the Moine Supergroup. Oykel Bridge, [NC 386 009]. Rock outcrop is approximately $6 \mathrm{~m}$ high, (BGS Photograph P005824).

- Strutture a mullion nelle rocce psammitiche della Formazione di Altnaharr (Gruppo di Morar), appartenenti al Supergruppo di Moine, affioranti nei pressi di Oykel Bridge (Coordinate: NC 386 009). L'altezza dell'ffioramento è di circa 6 metri (Fotografia del British Geological Survey n. P005824).

attention after the rather cursory primary survey (READ et alii, 1926) though the studies of the now classic, columnar, SE-plunging mullion lineations at Oykel Bridge are a notable exception (fig. 2, WILSON 1953). These mullions were described and interpreted by Clough (in РЕACH et alii, 1912) as formed by «pressures from four sides in opposite pairs, leaving constituents to squeeze out...» effectively describing a constrictional strain ellipsoid. READ et ali (1926) thought that the mullions were formed by two separate deformation phases, the first being contraction in a NE-SW direction, the second extension along a NW-SE axis, with the latter phase clearly linked to movement along the Moine Thrust; «the stretching is in harmony with the dip of the Moine Thrust $[\ldots]$ and may be regarded as an obvious accompaniment of the thrust-movement (the northwest». In contrast, WILSON (1953), viewed the mullions as the product of 'rolling or shearing movements acting at

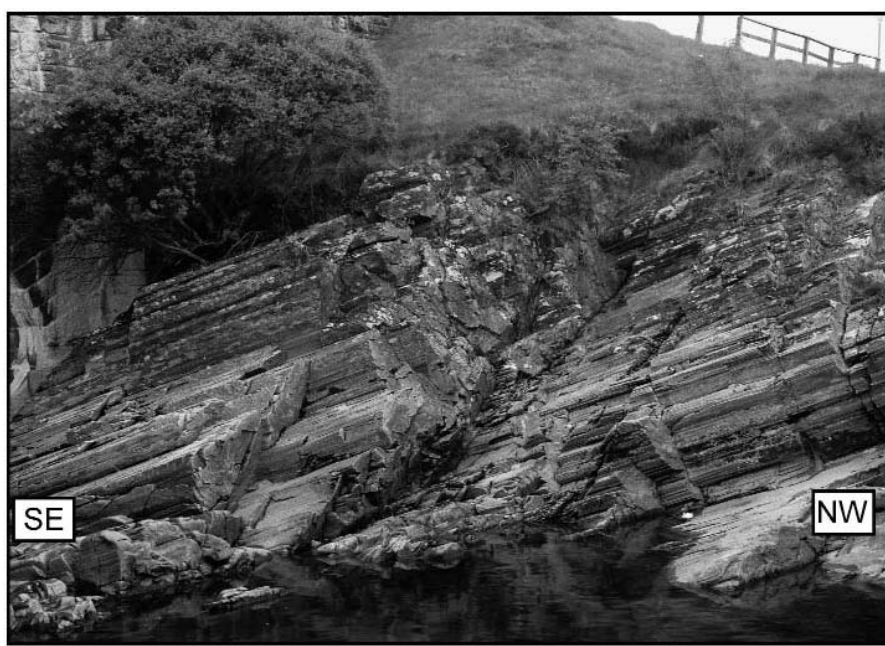

right angles to their lengths'. At a time when it was not appreciated that folds could form, or be rotated, parallel to the transport direction, Wilson thus denied any component of stretching parallel to the mullion axes (WILSON, 1953), and hence any direct relationship between the formation of the mullions at Oykel Bridge and of the Moine Thrust, or any other NW-directed thrusting.

\section{GEOLOGICAL SETTING}

Movement along the Moine Thrust Belt is regarded as Silurian in age (van BREemen et alii, 1979; Johnson et alii, 1985; KeLLEY, 1988; FreEman et alii, 1998; Dallmeyer et alii, 2001; StRACHAN $e$ alii, 2002). Shortening across the belt has been estimated of the order of 50-80 km (e.g. LAPWORTH, 1885; РЕACH et alii, 1907; SOPER \& Wilkinson, 1975; Elliott \& Johnson, 1980; McClay \& COWARD, 1981; BuTLER, 1982; ButLER et alii, 
Fig. 3 -Cross-sections showing thrust architecture in Assynt Culmination (after British Geological Survey 2007). No vertical exaggeration. Locations of section lines A-
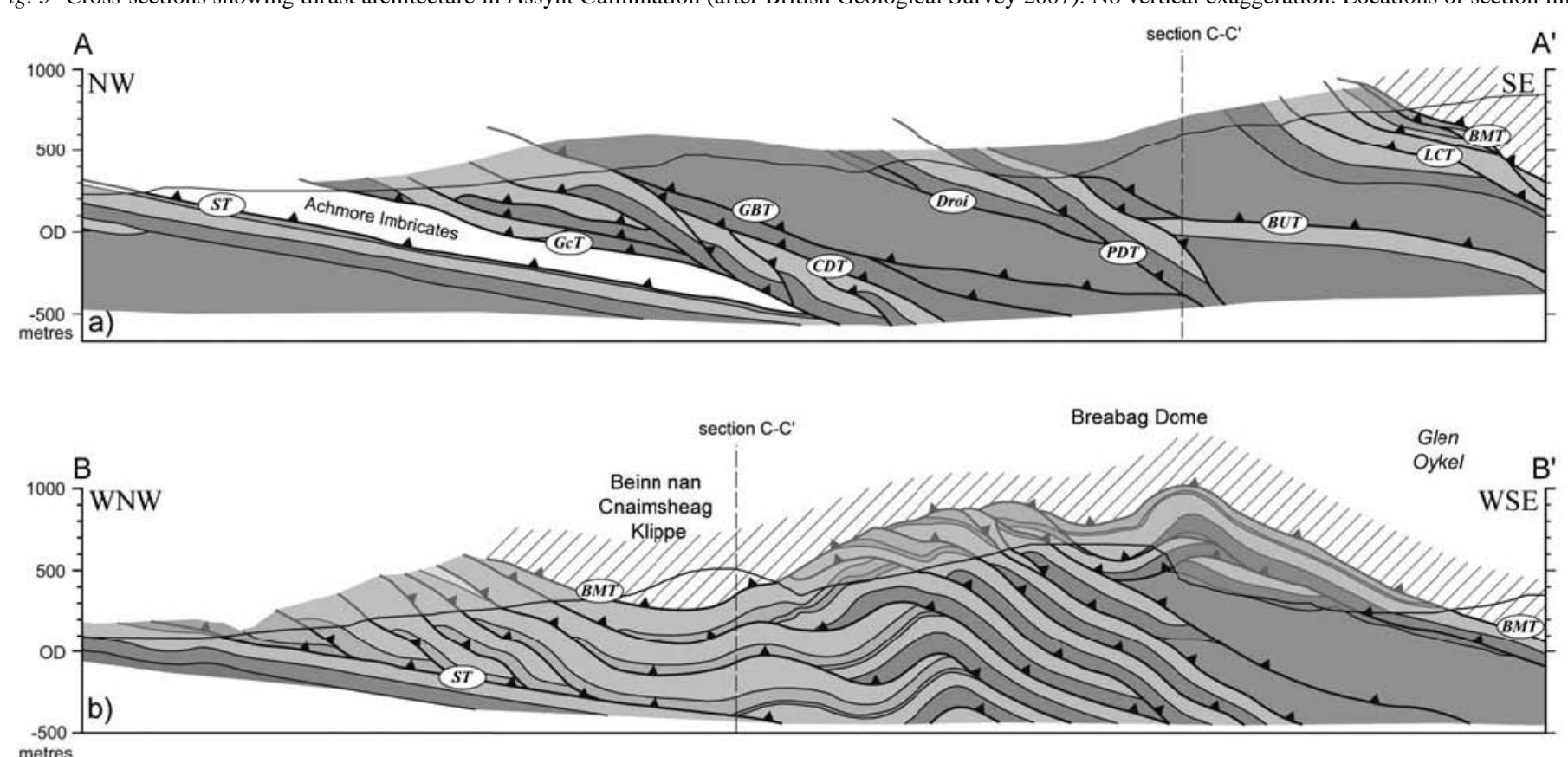

$\mathrm{A}^{\prime}$ and B-B' are indicated on fig. 5a. For key see fig. 4. Ben More Thrust sheet is hatched. BMT = Ben More Thrust, BUT = Beinn Uidhe Thrust, $C D T=C n o c$ Dubh Thrust, Droi = Cnoc an Droighinn Thrust, GBT = Glas Bheinn Thrust, GcT = Glencoul Thrust, PDT = Poll an Droighinn Thrust, ST = Sole Thrust: A-A' - cross-section across Droighinn area, north of Traligill Transverse Zone; B-B' - cross-section across Breabag-Stronchrubbie system, 2-3 km south of Traligill Transverse Zone. - Sezioni geologiche che mostrano la geometria dei sovrascorrimenti nella Culminazione di Assynt (da: British Geological Survey, 2007). Le tracce A-A $A^{\prime}$ e B-B $B^{\prime}$ delle sezioni sono indicate in fig. 5a. La scala delle distanze è uguale a quella delle altezze. Per la spiegazione dei simboli vedasi la fig. 4. La Falda del Ben More Thrust è indicata in tratteggio. BMT = Ben More Thrust; BUT = Beinn Uidhe Thrust; $C D T=$ Cnoc Dubh Thrust; Droi = Cnoc an Droighinn Thrust; GBT = Glas Behinn Thrust; GcT = Glencoul Thrust; PDT = Polla n Droighinn Thrust; $S T$ = Sole Thrust; A-A' = sezione attraverso il sistema di Breabag-Stronchrubbie, circa 2-3 km a sud del Lineamento Trasversale di Traligill.

2007). In some places the MTB is a single, simple thrust plane; elsewhere thrust sheets are piled on one another in stunning complexity. Thrust sheets vary in thickness from km-scale to less than $10 \mathrm{~m}$ and a wide range of different thrust geometries are present. Foreland and hinterland dipping-duplexes, anticlinal stacks, thrust nappes, foldnappes and lateral ramps all vie for attention (fig 3; BGS 2007, 2008; ButLer, 1982, 1984; ButLER et alii, 2007; COWARD, 1982, 1983, 1985; Elliot \& JohnSON, 1980). Variability along an east-west cross-section (along the thrust direction) can be readily explained by the very different rheological properties of the lithologies involved. Thin dolomitic siltstones and dolostones (Fucoid Beds Member, see below and fig. 4) comprise a particularly incompetent unit in which much of the thrust complexity is ultimately rooted.

Lithologies in the Moine Thrust Belt AND ITS ENVIRONS

Lithologies present in the thrust belt range from massive Lewisian Gneiss and thick-bedded Torridon Sandstone, to thin incompetent dolomitic siltstone layers sandwiched between CambroOrdovician dolostone and Cambrian quartz-arenite (fig. 4).

In the Foreland west of the MTB (figs. 1 \& 5a), the oldest rocks are in the Lewisian Gneiss Complex. Felsic to intermediate Archaean orthogneisses (Scourian Gneiss) are intruded by the Early Palaeoproterozoic mafic and ultramafic Scourie Dyke Swarm (PARK et alii, 2002). The complex is unconformably overlain by the early-

sidiary layers of pelite and semipelite. Though sedimentary structures are commonly deformed or obscured by regional metamorphism (but by no means obliterated), psammitic lithologies in low-strain areas have provided much sedimentological information (GLENDINNING, 1988; KRABBENDAM et alii, 2008). In
Neoproterozoic Torridon Group that is dominated by severa kilometres thickness of coarse red arkosic cross-bedded sandstone (Applecross Formation, STEWART, 2002).

The sub-Cambrian unconformity with the Torridon Group is a remarkably planar surface and the Cambro-Ordovician formations record an extremely uniform stratigraphical thickness along the 200 $\mathrm{km}$ strike length of the MTB from Durness to Skye, very much a 'layer-cake' stratigraphy (fig. 4; PARK et alii, 2002; Wright \& Knight, 1995; McKie, 1991; Prigmore \& Rushton, 1999; ArmSTRONG et alii, 2006). In that sequence, arenitic Basal Quartzite and Pipe Rock members of the Eriboll Formation are each 75-100 m thick. The younger Pipe Rock is characterised by abundant Skolithos 'pipes', distinctive trace fossils that form ideal strain markers (WILKInson et alii, 1975; COWARD \& KIM, 1981). The succeeding, and much thinner, An t-Sron Formation comprises dolomitic siltstone and dolostone of the Fucoid Beds Member (10-20 m thick) overlain by coarse quartz arenite of the Salterella Grit Member (c. 7 $\mathrm{m}$ thick). The siliciclastic Ardvreck Group is succeeded by the calcareous Durness Group, of which only the three lowest Ghrudaidh, Eilean Dubh and Sailmhor formations occur in Assynt (fig. 4).

The Neoproterozoic Moine Supergroup dominates the Northern Highlands east of the Moine Thrust (figs. 1 \& 5a; JoHnstone et alii, 1969; HoldSWORTH et alii, 1994; SOPER et alii, 1998). Only the structurally and stratigraphically lowermost Morar Group is relevant here. The group is siliciclastic and dominated by psammite with sub

such areas, bed thickness typically varies from $20 \mathrm{~cm}$ to over 300 $\mathrm{cm}$ and sedimentary structures such as cross-bedding nested crossbeds, and soft-sediment deformation are common and suggest deposition in a braid-plain fluvial setting. An original stratigraphical thickness of $>3 \mathrm{~km}$ can be demonstrated east of the Assynt in Glen 
Oykel, where a correlation with the Torridon Group in the Foreland has been suggested (KRABBENDAM et alii, 2008). Slices of Lewisian

Gneiss are exposed locally within the Moine outcrop, these represent the basement onto which the Moine rocks were deposited unconformably. 
That Cambro-Ordovician strata in the MTB show such remarkable lateral uniformity in thickness and lithology (e.g. PEACH et alii, 1907, p. 364; Prigmore \& Rushton, 1999), and are so intimately involved with thrusting (Fucoid Beds Member), begs the question why any strong lateral variability in kinematics and architecture should occur along strike in the thrust belt (fig. 1). The classic Assynt Culmination is the largest of several culminations within the MTB (fig. 5a), the Traligill Transverse Zone (TTZ) transects the Assynt Culmination (KRABBENDAM \& LESLIE in press, 2009). New BGS mapping has identified the large-scale Cassley Culmination in Moine rocks to the SE of, and structurally above, the Assynt Culmination (fig. 5a). The Oykel Transverse Zone (OTZ) controls the southern termination of the Cassley Culmination (LESLIE et alii, in press, 2009). These structures are reviewed in brief below.

\section{TRANSVERSE ZONES AND THE ASSYNT AND CASSLEY} CULMINATIONS

\section{Assynt Culmination}

The geology of the Assynt District is arranged around a bulge or culmination in the Moine Thrust plane (fig. 5a); the Assynt Culmination is enclosed within the trace of the thrust. Major individual thrust sheets broadly overlap each other within the culmination in such a way that the more northerly thrust sheets overlie those to the south. Thrust movement overall was to the WNW $\left(290^{\circ} \mathrm{N}\right.$, MCClay \& CowaRD, 1981); most thrusts dip gently to the ESE. The structurally highest, and also largest, thrust sheet is the Ben More Thrust Sheet (fig. 5a). With a strike length $>20 \mathrm{~km}$, this thrust sheet now dominates the eastern and northern part of the culmination (KrabBendam \& LesLle, 2004); small klippen of the Ben More Thrust Sheet occur farther west (fig. 3, section B-B'; РЕACH et alii, 1907; Coward, 1985), proving that the thrust sheet was formerly much more extensive. The floor thrust in the culmination is defined as the Sole Thrust (fig. 5a), although this is not necessarily one single thrust plane.

The Assynt Culmination is transected by the brittle-ductile Traligill Transverse Zone (TTZ). This WNW-ESE feature trends sub-parallel to the thrust transport direction, and is associated with an en echelon fault system cutting thrusts, discontinuity of the thrust architecture, and oblique fold and thrust structures (figs. 5a \& b). The

Fig. 4 -Generalised vertical section for Assynt, also to be used as key for figs. 3 \& 5b. Scale bar applicable to Cambro-Ordovician rocks only. See also PARK et alii (2002); British Geological Survey (2007).

- Sezione schematica attraverso la Culminazione di Assynt, da utilizzare anche per la lettura delle figg. 3 e 5 b. La scala si riferisce esclusivamente alle rocce della serie Cambro-Ordoviciana. Vedasi anche PARK et alii (2002) e British Geological Survey (2007).

effect of the TTZ on the Ben More and Moine thrusts in the east of the culmination is only minor; much more dramatic effects are evident below the Ben More Thrust to the WNW (figs. 5a \& 5b). Thick thrust sheets dominated by quartzite and Lewisian gneiss that occur to the north of the transverse zone contrast sharply with thin thrust sheets to the south that are dominated by carbonate rocks at outcrop (fig. 5b; see also BGS 2007). Piercing point analysis of the transverse system of faults proves that displacement occurred after deposition of the Cambro-Ordovician rocks and pre-, syn- and postthrusting (KRABBENDAM \& LeSLIE in press, 2009).

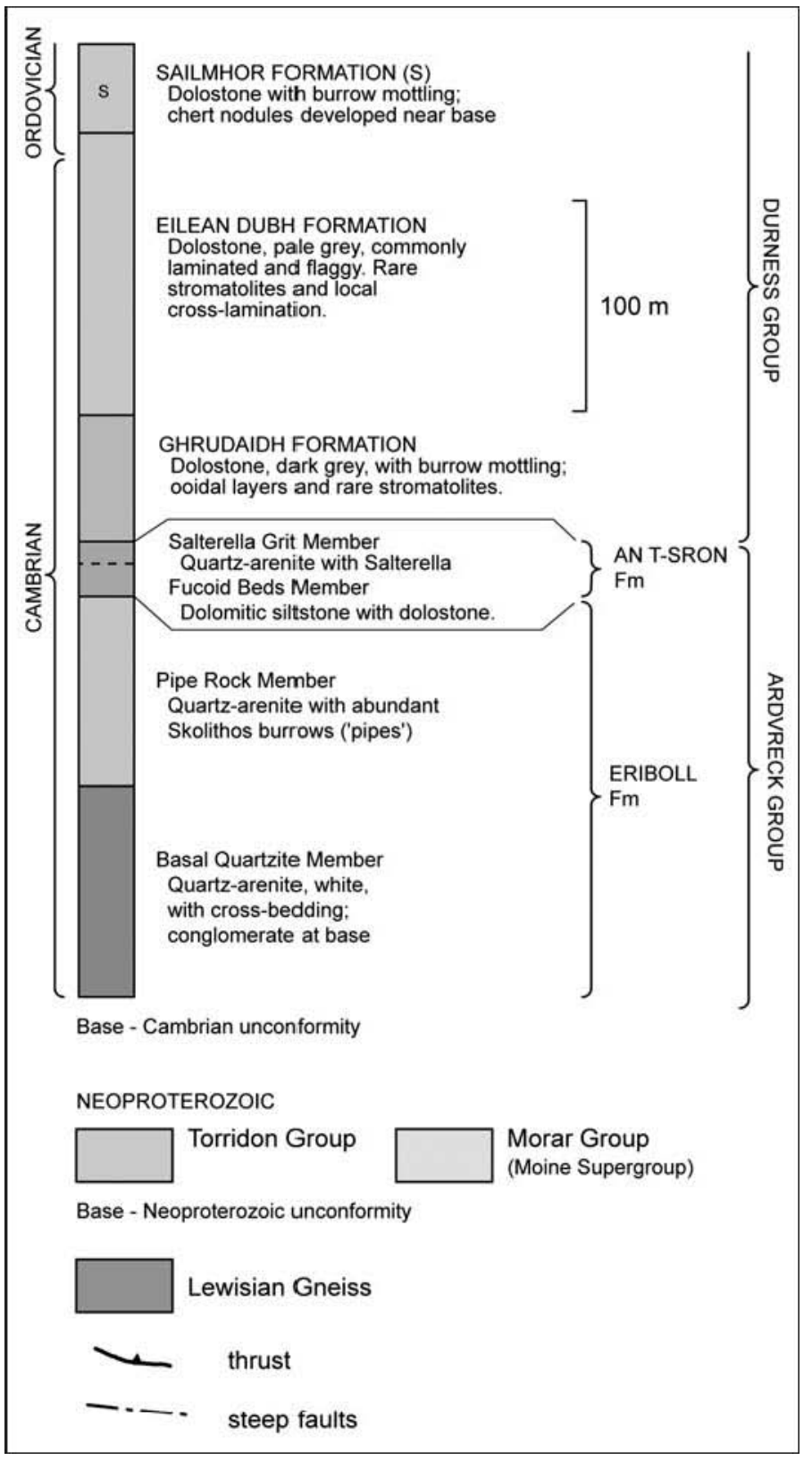


Fig. $5 a$-Geological map of the Assynt and Cassley culminations, with schematic cross sections through the Ben Hee (D-D') and Glen Cassley (E-E') areas. Locations of
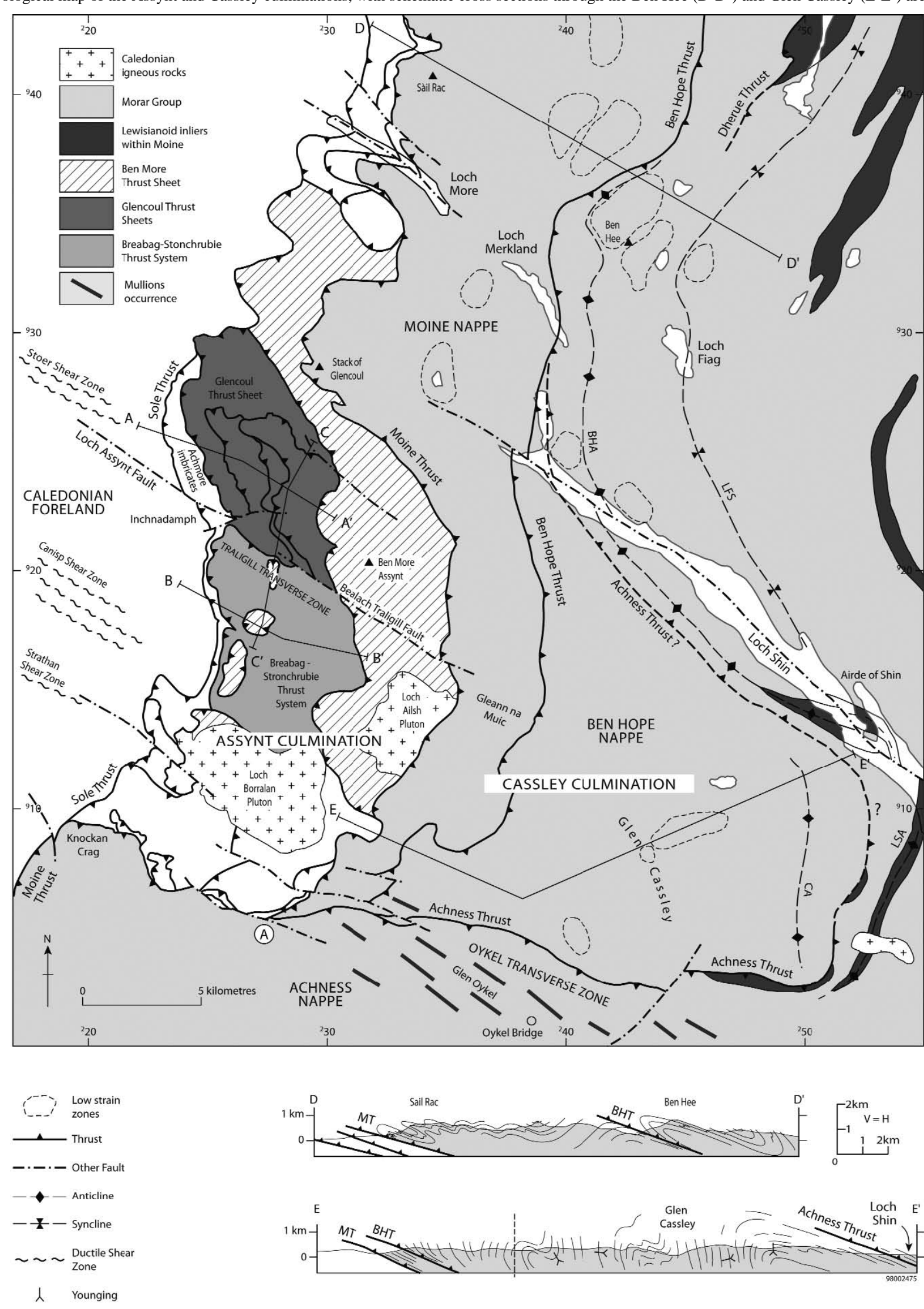

sections A-A , B-B (fig. 3) and C-C (fig. 5b) also shown. BHA = Ben Hee Anticline; CA = Cassley Anticline; LSA = Loch Shin Anticline; LFS = Loch Fiag Syncline. - Carta geologica delle Culminazioni di Assynt e di Cassley, corredata di sezioni schematiche attraverso le aree di Ben Hee (D-D') e Glen Cassley (E-E'). Ė indicata anche la traccia delle sezioni A-A', B-B' (fig. 3) e C-C'(fig. 5b). BHA = Anticlinale di Ben Hee; CA = Anticlinale di Cassley; LSA = Anticlinale di Loch Shin; LFS = Sinclinale di Loch Fiag. 
Fig. $5 b$-N-S cross-section C-C' across the Assynt Culmination and normal to transport direction, highlighting the complexity associated with the Traligill Transverse Zone; location of section line indicated on fig. 5a. For key see fig. 4. Ben More Thrust sheet is hatched. No vertical exaggeration. See also British Geological Survey (2007). BFT $=$ Beinn an Fhurain Thrust, BMT $=$ Ben More Thrust, BUT $=$ Beinn Uidhe Thrust, Droi $=$ Cnoc an Droighinn Thrust, GBT $=$ Glas Bheinn Thrust, GcT $=$ Glencoul Thrust, LCT = Loch nan Cuaran Thrust, PDT = Poll an Droighinn Thrust, TT= Traligill Thrust, ST = Sole Thrust.

- Sezione C-C', con orientazione N-S attraverso la Culminazione di Assynt e perpendicolare alla direzione del trasporto tettonico, che mostra le complessità associate

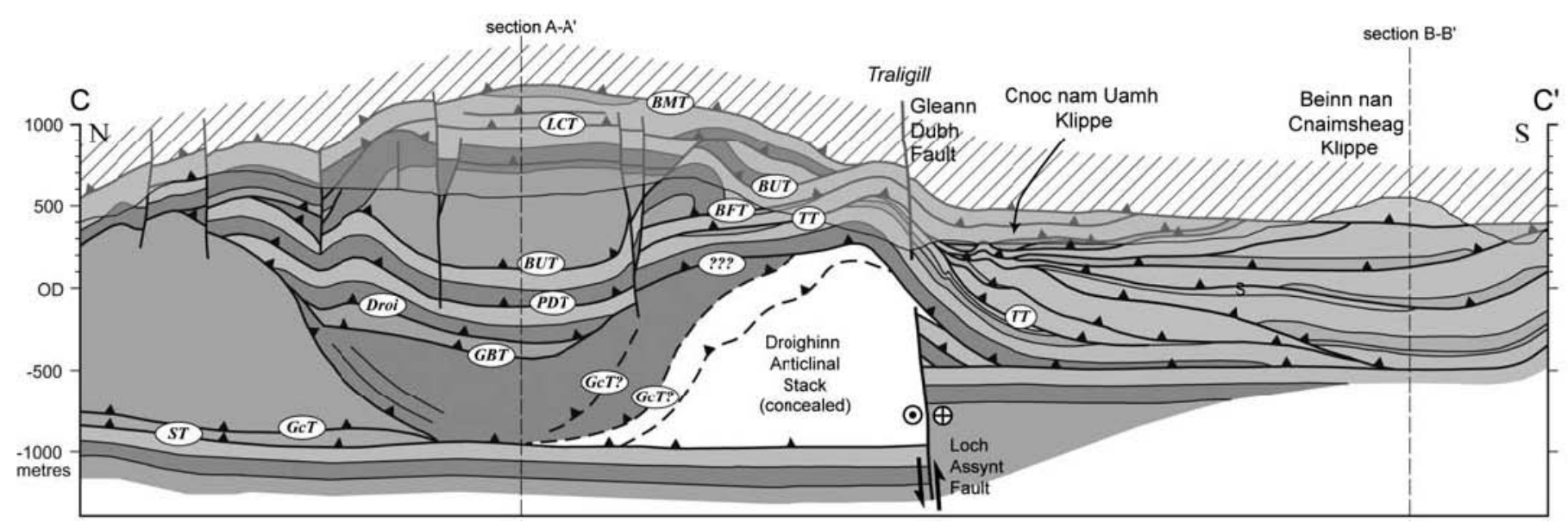

al Lineamento Trasversale di Traligill (la traccia della sezione è indicata in fig. 5a). Per i simboli vedasi la fig. 4. La Falda del Ben More Thrust è indicata in tratteggio. La scala delle distanze è uguale a quella delle altezze. Vedasi anche British Geological Survey (2007). BFT = Beinn an Fhurain Thrust; BMT = Ben More Thrust; BUT = Beinn Uidhe Thrust; Droi = Cnoc an Droighinn Thrust; GBT = Glas Bheinn Thrust; GcT = Glencoul Thrust; LCT = Loch nan Cuaran Thrust; PDT = Polla n Droighinn Thrust; TT = Traligill Thrust; ST = Sole Thrust.

\section{CAssley Culmination}

The Cassley Culmination lies to the ESE of the Assyn Culmination in the hanging wall of the Moine Thrust, both culminations are of comparable scale (fig 5a; see also BGS in press b, 2009). The Achness Thrust is identified as the roof thrust to the Cassley Culmination, the Moine Thrust defines the floor. The Ben Hope Thrust lies between the Achness and Moine thrusts (fig. 5a); the transport direction of each component nappe is top-to-the-WNW or NW on these thrusts. The Ben Hope and Achness thrusts converge with the Moine Thrust at the SE corner of the Assynt Culmination (point A on fig. 5a), thus delimiting the Cassley Culmination in the south and southwest. This southern lateral termination of the culmination is marked by a km-scale thick slab of strongly deformed and foliated, steeply southward-dipping planar psammite lying in the hanging wall of the WNW-ESE sector of the Achness Thrust (fig. 5a); a well-defined culmination wall.

Critical evidence of the foreland-propagating deformation which built this culmination is seen in the culmination wall where the main phase planar schistosity in the structurally higher Achness Nappe is deformed by the main phase folds of the structurally lower Ben Hope Nappe (LesLie et alii in press, 2009). The culmination wall coincides with a prominent belt of mullion structures which includes the classic Oykel Bridge locality (WILson, 1953; fig. 2). All of these mullions plunge SE; critically the mullions occur in both the Ben Hope and Achness thrust sheets (crossing the trace of the Achness Thrust), and deform earlier colinear fabrics in the Achness Nappe. Together, all of these structural features at the southern termination of the Cassley Culmination characterise the ductile Oykel Transverse Zone (OTZ); the highly deformed lithologies in the OTZ strike broadly perpendicular to the overall trend of the thrust front, but approximately parallel to the regional thrust transport direction (fig. 5a). LesLIE et alii (in press, 2009) provide a more detailed description and analysis.

\section{Growth of the CASSLEy CULmination}

In the evolution of the Cassley Culmination (fig. 6, but see also LesLIE et alii, in press, 2009), tight-to-isoclinal folds formed first within the structurally highest Morar Group rocks in the incipient Achness Nappe. The earliest time slice in fig. 6 represents focussed slip on the Achness Thrust plane. As contraction continued, translation stuck on the Achness thrust plane and strain consequently began to transfer down into the footwall rocks. WNWvergent fold systems then developed in the incipient Ben Hope Nappe. The Achness Thrust and structurally overlying folds were bulged upward in the developing culmination. Earlier formed folds began to rotate towards the present downward-facing attitude in the culmination wall and mullions begin to form.

Strain then became focussed on the Ben Hope Thrust; a branch line joining the Achness and Ben Hope thrusts was oriented (sub)parallel to transport direction and the culmination and the OTZ became more sharply defined. In time, that process repeated; translation stuck on the Ben Hope Thrust plane, strain transferred downwards into the footwall of the Ben Hope Thrust. Finally, movement occurred throughout the region on the Moine Thrust. The development of the Moine Thrust and the degree and thickness of the associated mylonitic rocks seems to be broadly similar north and south of the OTZ, in contrast to the control exerted by the latter on the localisation of strain prior to this stage. Mullion development ceased in the OTZ. In a new phase of brittle-ductile behaviour, strain transferred into the footwall of the Moine Thrust and the Assynt 
Fig. 6 -Structural evolution of Oykel Culmination. Sections in the left-hand column look down the regional transport direction to the SE,

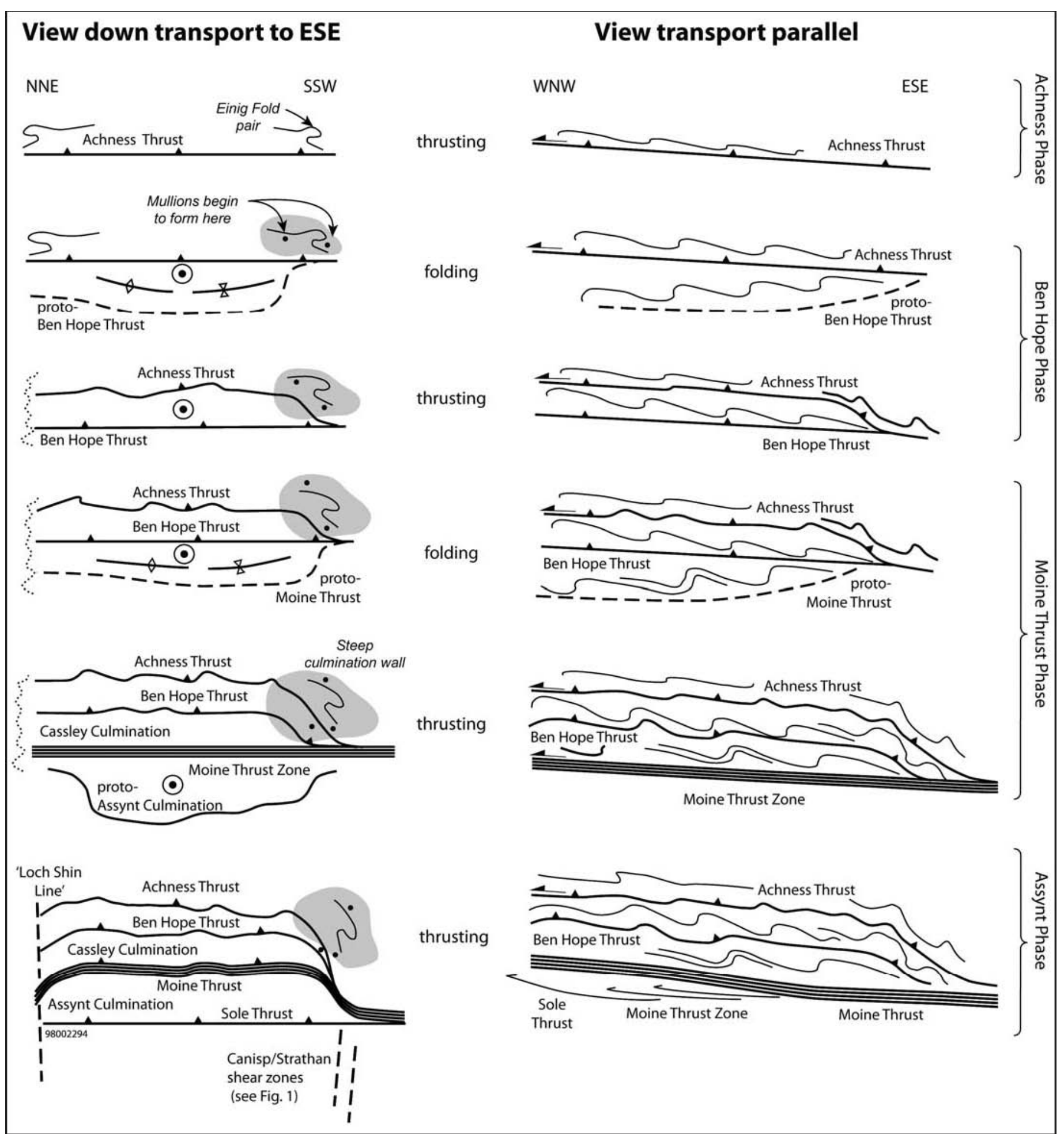

i.e. down-plunge on the mineral/stretching/mullion lineation. Sections in the right-hand column are constructed parallel to the transport direction.

Evoluzione strutturale della Culminazione di Oykel. Le sezioni nella colonna di sinistra sono orientate perpendicolarmente alla direzione del trasporto tettonico e sono allineate nel senso dell'immersione assiale, coerentemente con la lineazione mineralogica, di estensione e dei mullion. 
Culmination began to develop below the Cassley Culmination, leading to further uplift of that structure and further steepening in the OTZ.

The evolution of the Cassley Culmination is characterised by alternating development of folds and thrusts,

i.e. an alternation of distributed and focussed strain. To maintain strain compatibility, the Achness Nappe south of the culmination wall must have kept moving towards the NW in a quasi-continuous fashion along the Ullapool to Knockan Crag sector of the (proto-) Moine Thrust at the same time as the structurally lower Ben Hope Thrust and its associated folding developed (fig. 1). In this scenario, there must have been periods of differential movement along the OTZ. A dextral shear-couple would have resulted when rocks in the Ben Hope Nappe were folding, and thus moving NW-ward relatively more slowly than those of the Achness Nappe south of the OTZ. We argue elsewhere (LeSLIE et alii, in press, 2009), that the observed counter-clockwise angle angle between the strike of the steepened culmination wall and the thrust transport direction would result in dextral transtension. Transtension under such circumstances would generate a prolate strain ellipse (constriction) under most boundary conditions (DEWEy et alii, 1998, and references therein; Fossen \& TiкоFF, 1998) and would thus provide a plausible explanation for the formation of the mullion structures during culmination building.

\section{TRANSVERSE ZONES, THEIR ORIGIN, AND THE ARCHITECTURE} OF THE MOINE THRUST BELT

Transverse zones in thrust systems are commonly understood to be coincident with, and caused by, deeper-seated pre-existing structural features. They have been documented mainly in the brittle, thin-skinned external parts of fold-and-thrust belts (e.g. Thomas, 1990; Paulsen \& MarshaK, 1999). The TTZ represents a brittle-ductile manifestation of such a transverse structure in the external Caledonides of the NW Highlands whilst the OTZ formed at deeper levels as a ductile response in the orogen interior. Krabbendam and Leslie (in press 2009, fig. 9) examine possible templates which might have acted to constrain both of these transverse zones. For the TTZ (KrabBendam \& LesLiE (in press 2009), we have shown that there is good evidence for displacement on a basement fault (Loch Assynt Fault) that affected overlying strata. The cover strata, and the planar unconformity at their base, were faulted prior to thrusting that scenario is reproduced here in fig. 7. Such a fault would clearly affect thrust architecture where only cover sequence was involved; even more pronounced effects would be expected where both basement and cover was involved.

The results of sand-box modelling by CALAssou et alii (1993) are instructive for understanding the generation of the TTZ. In that analogue study, the effects of a basement fault in the footwall exactly parallel to the thrust direction, but with a uniform hanging wall, were examined. Those experiments showed:

-lateral inter-fingering of thrust sheets, both in map view and in cross-section along the transverse zone;

- thrusts developing above the down-thrown side of the basement fault propagating further on the foreland, defining a bend in the thrust front;

Fig. 7 -Possible lateral variation in pre-thrusting template defined by a pre- and post-depositional fault in basement displacing cover strata after deposition. The thrust architecture that would potentially result during shortening aligned slightly oblique to the pre-existing fault-step is reproduced behind (see also fig. 5b). - Possibile variazione laterale nella ricostruzione palinspastica pre-thrusting, definita da una faglia con attività sia pre- che post-deposizionale, che interessa il basamento $e$ che ha troncato gli strati della copertura sedimentaria successivamente alla loro deposizione. Viene anche mostrata in secondo piano l'architettura dei sovrascorrimenti che si otterrebbe attraverso un raccorciamento leggermente obliquo rispetto al gradino controllato dalla faglia pre-orogenica (vedasi anche la fig. $5 b$ ).

-a different thrust geometry in the compartments on either side of the transverse zone, with fewer but thicker thrust sheets on the downthrown side.

These features are similar to the situation across the TTZ. We argue
(KRABBENDAM \& LESLIE in press, 2009) that the angular relationship between the strike of the pre-existing fault and the subsequent thrust transport direction must also be taken into account. There is a small angle between the strike of the Loch Assynt Fault $\left(305^{\circ} \mathrm{N}\right)$

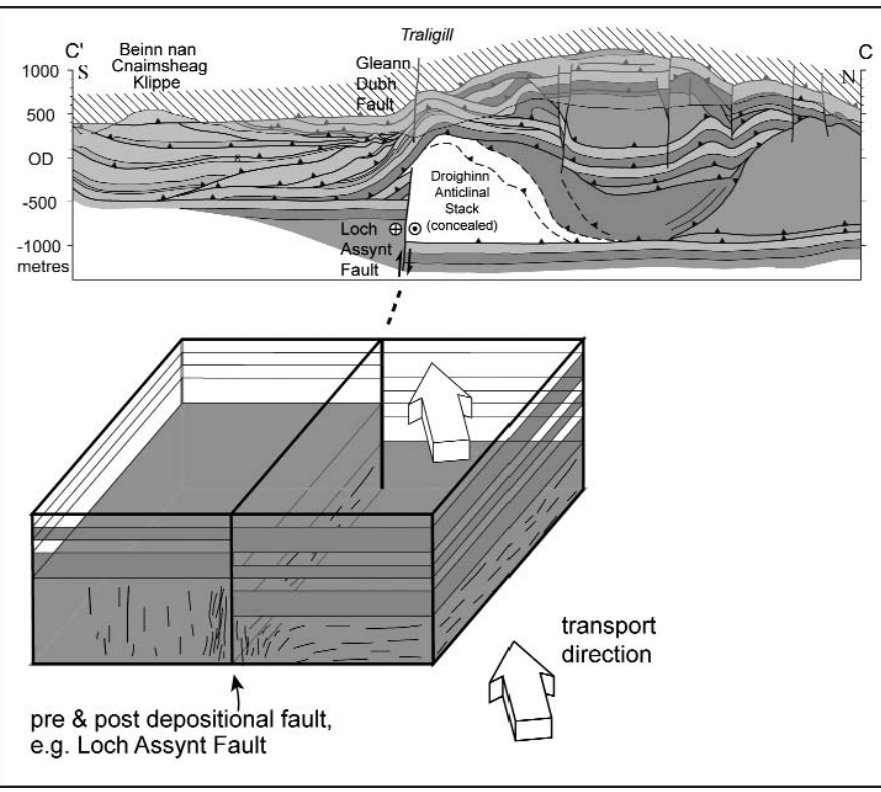

and the thrust transport direction (c. $290^{\circ} \mathrm{N}$; McClay \& CowARD, 1981). If, in the model of fig. 7, the transport direction is counterclockwise from the strike of the fault, thrusts need to ramp up and over the basement step, and local transpression is expected. The scale and complexity of the disturbance associated with the TTZ would grow larger with time, starting from an original relatively minor disturbance, explained, at least in part, by oblique 'piling-up' of thrust sheets against the initial basement step in sinistral transpression.

\section{A BASEMENT CONSTRAINT FOR THE LOCATION OF} THE OYKel TRANSVERSE Zone?

Although the stratigraphical constraints in the Cassley Culmination are much less clear, we envisage that the OTZ originated in a similar manner to the TTZ such that the Lewisian/Moine basement-cover interface was displaced prior to thrusting, (possibly during and after thrusting as well). The contrast between the numerous branching thrusts which make up the Cassley (ductile) 
and Assynt (brittle-ductile) culminations, and the regions of folded, but not internally thrust, Moine rocks to the south of the OTZ, is also reproduced in the analogue modelling of Liu Huiol et alii (1991), MALAVEILLE et alii (1991) and CALASSOU et alii (1993). Where basement is vertically offset, lateral thrust ramps have their roots in the basal discontinuity and these ramps steepen as thrusting continues to excavate new thrust packages during forelandpropagation (Thomas, 1990; Calassou et alii, 1993; Paulsen \& MarschaK, 1999)

We can see no reason that the location of the OTZ should have been determined by lateral variations within the Moine rocks; no systematic change in lithological character, lithostratigraphy or gross thickness of these psammitic units occurs across the termination wal which might control rheology and therefore constrain the geometry and location of the developing culmination. Instead, our new modelling of the regional gravitational field data implies that the location of the OTZ was strongly influenced by a prominent NW-SE trending buried ramp, or series of steps, in the Lewisian basement/cover interface (LESLIE et alii in press, 2009). The locus fo the OTZ is directly comparable to the reactivated NW-SE trending basement shear zone that is judged to have constrained the location of the TTZ (KRABBENDAM \& LESLIE in press, 2009).

\section{ISVERSE ZONES IN THE MOINE THRUST BELT AND MOINE NAPPE}

The Lewisian gneiss basement in the Foreland of the Moine Thrust Belt contains a number of WNW-ESE striking Palaeoproterozoic shear zones (fig. 1; Coward \& Park, 1987; Attfield, 1987; Beacom et alii, 2001; Kinny et alii, 2005). These re-activated sub-vertical basement shear zones have a long history of repeated movement prior to deposition of the Cambro-Ordovician succession on the Foreland (ВеAсом et alii, 2001); critically, the regional gravity data permits extrapolation of these important structures beneath the Moine outcrop. Krabbendam \& LesLie (in press 2009) review the varied impact that these structures may have had upon the architecture of Caledonian thrusting in the Northern Highlands of Scotland.

The Stoer Shear Zone was reactivated as the Loch Assynt Faul prior to thrusting and underlies the Traligill Transverse Zone (fig. 5a). The Canisp Shear Zone is associated with a monoclinal steepening of the fabric in the Lewisian basement (e.g. ATTFIELD, 1987) and demonstrable brittle reactivation (BЕAсOM et alii, 2001). Although, the Sole Thrust and base-Cambrian unconformity in the Foreland are not appreciably displaced, the Canisp (and Strathan) Shear Zone does line up with the approximate southern terminatio of the Ben More Thrust Sheet (BGS 2007), and the OTZ (fig. 5a). The Laxford Shear Zone also coincides with significant lateral variation in the northern part of the MTB (fig. 1). The Bhuirich Dome (ButLer, 1984; British Geological Survey, 2007) may have rooted, at least in part, above the Laxford Shear Zone. It should be noted, in addition, that for some $30 \mathrm{~km}$ south of the Assynt Culmination, there are only a few small-scale culminations (BGS 2008), and that the Moine Thrust over much of this segment is simple, smooth structure.

Overall, it seems clear that the lateral variations in thrus architecture along the length of the Moine Thrust Belt are strongly influenced by the existence of Proterozoic shear zones, and the brittle faults that commonly developed later along the older shear zones.
Other faults or shear zones appear to have had little influence however. These different relationships depend probably upon the nature of any Neoproterozoic or Palaeozoic (brittle) reactivation experienced by the pre-existing structures, and displacement of the Torridon or Cambro-Ordovician cover sequences. Exploiting these NW-SE shear zones during Iapetan rifting has the potential to create transfer faults separating normal-fault blocks (c.f. Lister et alii, 1986). Where continental collision and related thrusting is approximately frontal with respect to the older, rifted passive margin it deforms, then that inherited template will act strongly to control the architecture of fold-andthrust belts. The older transfer systems can thus be expressed as the transverse structures accommodating lateral changes in the 3-D architecture of the thrust belt.

\section{CONCLUSIONS}

The Traligill Transverse Zone in the Assynt Culmination, and the Oykel Transverse Zone at the southern termination of the Cassley Culmination, mark pronounced lateral changes in thrust architecture along the Moine Thrust Belt and the internal parts of the Caledonian orogen respectively. The Traligill Transverse Zone overlies a preexisting fault (Loch Assynt Fault), oriented at small angles to the thrust transport direction. The Oykel Transverse Zone lies above the SE continuation of the Canisp/Strathan shear zones beneath the foldand-thrust belt. Pre-thrust faulting displaced both basement and cover strata, creating a step, or series of steps, in basement. The resultant transverse zones are much larger in scale than the amplitude of the original step $(100 \mathrm{~m}$ in the case of the Traligill Transverse Zone). That relatively small disturbances in the prethrusting template can lead to significant lateral variations in thrus geometry, may be the result of oblique, transpressional thrus stacking. In the OTZ, alternating focussed and distributed strain resulted in occasional periods of differential, dextral strike-slip which is the classic mullion structures observed at Oykel Bridge.

ACKNOWLEDGEMENTS

AGL and MK publish with the permission of the Director, British Geological Survey.

\section{REFERENCES}

ArmStrong H., Raine R. \& Smith M.P. (2006) -Iapetus. From coast to coast. ICOS 2006 post-conference field trip, University of Birmingham, Birmingham.

ATTField P. (1987) -The structural history of the Canisp Shear Zone. In: PARK R.G. \& TARNEY J. (Eds.). Evolution of the Lewisian and comparable PARK R.G. \& TARNEY J. (Eds.). Evolution of the Lewisian and comparable
Precambrian high grade terrains. Geological Society Special Publication, 27, 165-173.

BeACOM L.E., HoldsWorth R.E., McCAFFrey K.J.W. \& ANDERSON T.B. (2001) -A quantitative study of the influence of pre-existing compositional and fabric heterogeneities upon fracture-zone developmen during basement reactivation. In: HoLDSWORTH R.E., StRACHAN R.A. MACGLOUGHLIN J.F. \& KNIPE R.J. (eds.). The 
nature and significance of fault zone weakening, 186. Special Publication of the Geological Society of London, 195-211.

BÉGIN N.J. \& SPRATT D.A. (2002) -Role of transverse faulting in along-strike termination of Limestone Mountain Culmination, Rocky Mountain thrustand-fold belt, Alberta, Canada. Journal of Structural Geology, 24, 689-707.

British Geological SuRvey (1997) -Tongue. Scotland. British Geological Survey, Keyworth, Nottingham, 50000 .

BRITISH GEOLOGICAL SURVEY (2002) -Loch Erribol. Scotland. British Geological Survey, Keyworth, Nottingham, 50000

BRITISH GeOLoGical SuRvey (2007) -Assynt. Scotland Special Sheet. Bedrock. 1:50 000 Geology Series. British Geological Survey, Keyworth, Nottingham.

BRITISH Geological SURVey (2008) -Ullapool. Scotland... 1:50 000 Geology Series. British Geological Survey, Keyworth, Nottingham.

BRITISH Geological SuRVEY - In press, a. Ben Hee. Scotland. Bedrock. 1:50,000 Geology Series. British Geological Survey, Keyworth, Nottingham.

British Geological Survey - In press, b. Glen Oykel. Scotland. Bedrock 1:50,000 Geology Series. British Geological Survey, Keyworth, Nottingham.

BUTLER R.W.H. (1982) -The terminology of structures in thrust belts. Journal of Structural Geology, 4, 239-245.

BUTLER R.W.H. (1984) -Structural evolution of the Moine Thrust Belt between Loch More and Glendhu, Sutherland. Scottish Journal of Geology, 20, 161 179.

BUtLER R.W.H. (1987) -Thrust sequences. Journal of the Geological Society of London, 144, 619-634.

ButLer R.W.H., TAVARNelli E. \& Grasso M. (2006) -Tectonic inversion and structural inheritance in mountain belts. Journal of Structural Geology, 28 1893-1908.

ButLeR R.W.H., MATTHEWS S.J. \& MoRgan R.K. (2007) -Structural evolution of the Achnashellach Culmination, southern Moine thrust belt; testing the duplex model. In: RIEs A.C., ButLER

R.W.H. \& GRAHAm R.H. (eds.). Deformation of the continental crust; the legacy of Mike Coward. Geological Society Special Publications, 272, 103120.

Calassou S., Larroque C. \& Malavieille J. (1993) -Transfer zones of deformation in thrust wedges; an experimental study. Tectonophysics, 221 325-344.

COWARD M.P. (1982) -Surge zones in the Moine Thrust Zone of NW Scotland. Journal of Structural Geology, 4, 247-256.

COWARD M.P. (1983) -The thrust and shear zones of the Moine Thrust Zone of NW Scotland. Journal of the Geological Society of London, 140, 795-811.

CowARD M.P. (1985) -The thrust structures of southern Assynt, Moine thrust zone. Geological Magazine, 122, 596-607.

COWARD M.P. \& KIM J.H. (1981) -Strain within thrust sheets. In: MCCLAY K.R. \& PrICE N.J. (Eds.). Thrust and Nappe Tectonics. Geological Society Special Publication, 9, London, 275-292.

COWARD M.P. \& PARK R.G. (1987) -The role of mid-crustal shear zones in the Early Proterozoic evolution of the Lewisian. In: PARK

R.G. \& TARNEY J. (Eds.). Evolution of the Lewisian and Comparable Precambrian High Grade Terrains. Geological Society Special Publication, 27, 127-138.

Dallmeyer R.D., Strachan R.A., Rogers G., Watt G.R. \& Friend

C.R.L. (2001) -Dating deformation and cooling in the Caledonian thrus nappes of north Sutherland, Scotland: insights from 40Ar/39Ar and Rb-Sr chronology. Journal of the Geological Society, 158, 501-512.

Dewey J.F., Holdsworth R.E. \& StRACHAN R.A. (1998) -Transpression and transtension zones. In: HolDSworTH R.E., STRACHAN R.A. \& DEWEY J.F.
(eds.) Continental transpressional and transtensional tectonics. Geological (eds.) Continental transpressional and tan
Society Special Publications, 135, 1-14.

ELLIOTT D. \& JoHNSON M.R.W. (1980) -Structural evolution in the northern part of the Moine thrust belt, NW Scotland. Transactions of the Royal Society of Edinburgh: Earth Sciences, 71, 69-96.

FERMOR P. (1999) -Aspects of the three-dimensional structure of the Alberto Foothills and Front Ranges. Geological Society of America Bulletin, 111, 317-346.

Fossen H. \& TIKOFF B. (1998) -Extended models of transpression and transtension, and application to tectonic setting In: HOLDSWORTH R.E., STRACHAN R.E. \& DEWEY J.F. (eds.). Continental transpressional and
transtensional tectonics. Geological Society Special Publications, 135, 15-

Freeman S.R., Butler R.W.H., ClifF R.A. \& ReX D.C. (1998) Direc dating of mylonite evolution; a multi-disciplinary geochronological study from the Moine thrust zone, NW Scotland. Journal of the Geological Society of London, 155, 745-758.

Geological SuRvey of Great Britain (1923) -Geological map of the Assynt District Scotland, 1:63 360.

GLENDINNING N.R.W. (1988) -Sedimentary structures and sequences within a late Proterozoic tidal shelf deposit; the upper Morar Psammite Formation of northwestern Scotland. In: WINCHESTER

J.A. (eds.). Later Proterozoic stratigraphy of the Northern Atlantic Regions.

HEIM A. (1878) -Untersuchungen über den Mechanismus der Gebirgs- bildung: Im Anschluss an die geologische Monographie der TödiWindgällen-Gruppe. 2 vols. and atlas. Basle: Benno Schwabe.

HOLDSWORTH R.E., STRACHAN R.A. \& HARRIS A.L. (1994) -The Moine Supergroup. In: GiBBons W. \& HARRIS A.L. (eds.). A Revised Correlation of Precambrian rocks in the British Isles, 22, Geological Society of London Special Report, 23-32.

JoHnson M.R.W., KelLey S.P., Oliver G.J.H. \& WinTeR D.A. (1985) Thermal effects and timing of thrusting in the Moine Thrust zone. Journal of the Geological Society of London, 142, 863-874.

JoHnStone G.S., Smith D.I. \& HARRIS A.L. (1969) -The Moinian Assemblage of Scotland. In: North Atlantic Geology and continental Drift: a Symposium (edited by Kay M.), 159-180.

KeLLEy S.P. (1988) -The relationship between K-Ar mineral ages, mica grain sizes and movement on the Moine Thrust Zone, NW Highlands, Scotland. Journal of the Geological Society of London, 145, 1-10. KINNY P.D., FRIEND C.R.L. \& Love G.J. (2005) -Proposal for a terranebased nomenclature for the Lewisian Gneiss Complex of NW Scotland. Journal of the Geological Society of London, 162, 175-186.

Krabbendam M. \& LesLie A.G. (2004) -Lateral ramps and thrust terminations: an example from the Moine Thrust Zone, NW Scotland. Journal of the Geological Society of London, 161, 551-554.

Krabbendam M., Prave A.P. \& Cheer D. (2008) -A fluvial origin for the Neoproterozoic Morar Group, NW Scotland; implications for TorridonMorar group correlation and the Grenville Orogen Foreland Basin. Journal of the Geological Society of London, 165, 379-394.

Krabbendam M. \& LesLie A.G. (2009) -The Traligill Transverse Zone: lateral variations and linkages in thrust geometry in the Assynt Culmination, Moine Thrust Belt, NW Scotland. In: LAW R., BUTLER R.W.H., Strachan R. \& Krabbendam M. (eds.). Continental Tectonics and Mountain Building. Geological Society Special Publication.

LAPWORTH C. (1883) -The Secret of the Highlands. Geological Magazine, decade 2, 10, 120-128.

LAPWORTH C. (1884) -On the structure and metamorphism of the rocks of the Durness-Eriboll district. Proceedings of the Geologists' Association, 8, 438-442.

LAPWORTH C. (1885) -The highland controversy in British geology. Nature, London, 32, 558-559.

LAUBSCHER H.P. (1985) -Large-scale, thin-skinned thrusting in the southern Alps; kinematic models. Geological Society of America Bulletin, 96, 710718

Leslie A.G., Krabbendam M., Kimbell G.S. \& Strachan R.A. (2009, in press) -The Oykel Transverse Zone: linking mullions, regional gravity, and large-scale lateral variations in ductile thrust architecture in the Moine Nappe, Northern Highlands, Scotland. In: LAW R., BUTLER R.W.H., Strachan R.A. \& KRABBendam M. (Eds.). Continental tectonics and mountain building: the legacy of Peach and Horne. Geological Society Special Publication

LISTER G.S., ETHERIDGE M.A. \& SYMONDS P.A. (1986) -Detachment faulting and the evolution of passive continental margins. Geology, 14, 246-250. 
Liu Huili, McClay K.R. \& Powell D. (1991) -Physical models of thrust wedges. In: R.M.K. (eds.). Thrust tectonics Chapman \& Hall, London, 7180.

Malaveille J., Calassou S., Larroque C., Lallemand S. \& Stephan J.F. (1991) -Experimental modelling of accretionary wedges. Terra Abstracts, $\mathbf{3}$, 367.

McCLAY K.R. (1992) -Thrust tectonics Chapman and Hall, London.

MCCLAY K.R. (2004) -Thrust tectonics and hydrocarbon systems. AAPG

Memoir, 82.
MCCLAY K.R. \& CowARD M.P. (1981) -The Moine Thrust Zone: an overview. In: McClay K.R. \& PRICE N.J. (eds.). Thrust and Nappe Tectonics. Geological Society Special Publication, 9, London, 241-260.

MCKIE T. (1990) -Tidal and storm influenced sedimentation from a Cambrian transgressive passive margin sequence. Journal of the Geological Society of

London, 147, 785-794.
MirRA S. (1988) -Three-dimensional geometry and kinematic evolution of the Pine Mountain thrust system, Southern Appalachians.

Murchison R.I. (1849) - On the geological structure of the Alps, Apennines and Carpathians, more especially to prove a transition from secondary to Tertiary rocks, and the development of Eocene deposits southern Europe. Quarterly Journal of the Geological Society of London, 5, 157-312.

OLDROYD D.R. (1990) -The Highlands Controversy: Constructing Geological Knowledge through Fieldwork in Nineteenth-Century Britain, University of

Chicago Press, Chicago.
Park R.G., StewART A.D. \& Wright D.T. (2002) -The Hebridean terrane. In: TREWIN N.H. (Eds.). The Geology of Scotland. Geological Society, London, 45-80.

Paulsen T. \& MARShaK S. (1988) -Charleston transverse zone, Wasatch Mountains, Utah; structure of the Provo Salient's northern margin, Sevie fold-thrust belt. Geological Society of America Bulletin, 110, 512-522.

Paulsen T. \& MARShaK S. (1999) -Origin of the Uinta Recess, Sevier fold-thrust belt, Utah; influence of basin architecture on fold-thrust belt geometry.

Tectonophysics, 312, 203-216.
PEACH B.N., GunN W. \& Others (1912) -The geology of Ben Wyvis, Carn Chuinneag, Inchbae and the surrounding country. Memoir of the Geological Survey of Great Britain.

Peach B.N., Horne J., Gunn W., Clough C.T., Hinxman L.W. \& Teall J.J.H. (1907) -The geological structure of the North-West Highlands of Scotland. Memoir of the Geological Survey of Great Britain, 668p, 52 plates.

PRIGMORE J.K. \& Rushton A.W.A. (1999) -Scotland: Cambrian and Ordovician of the Hebridean Terrane. In: Rushton A.W.A., OwEN A.W. Owens R.M. \& Prigmore J.K. (Eds). British Cambrian to Ordovician Stratigraphy. Geological Conservation Review Series, 18, Chapman \& Hall, 295-315.

ReAD H.H., Phemister J. \& LeE G.W. (1926) -The geology of Strath Oykel and Lower Loch Shin, Scotland.

SOPER N.J. \& WILKINSON P. (1975) - The Moine thrust and the Moine Nappe at Loch Eriboll, Sutherland. Scottish Journal of Geology, 11, 339-359. SOPER N.J., HARRIS A.L. \& STRACHAN R.A. (1998) -Tectonostratigraphy of the Moine Supergroup; a synthesis. Journal of the Geological Society of London, 155, 13-24.

STEWART A.D. (2002). The Later Proterozoic Torridonian Rocks of Scotland: their Sedimentology, Geochemistry and Origin. Geological Society Memoir, 24.

StRACHAN R., SMIth M., HaRRIS A.L. \& Fettes D.J. (2002) -The Northern Highland and Grampian terranes. In: TREWIN N.H. (Ed.). The Geology of Scotland. The Geological Society, London, 81-147.

Tavarnelli E., Butler R.W.H., Decandia F.A., Calamita F., Grasso M., AlVAREZ W. \& ReNDA P. (2004) -Implications of fault reactivation and structural inheritance in the Cenozoic tectonic evolution of Italy. In: CRESCENTI U., D’Offizi S., MerLinI S. \& SACCHI R. (Eds.). The Geology of Italy. Special Volume 1, Soc. Geol. It., 209-222.

THомаs W.A. (1990) -Controls on locations of transverse zones in thrus belts. Eclogae Geologicae Helvetiae, 83, 727-744.

van BReemen O., Aftalion M. \& Johnson M.R. (1979) -Age of the Loch Borrolan complex, Assynt and late movements along the Moine Thrus Zone. Journal of the Geological Society of London, 16, 489-495.

Wilkinson P., SOPER N.J. \& Bell A.N. (1975) -Skolithus pipes as strain markers in mylonites. Tectonophysics, 28, 143-157.

WILSON G. (1953) -Mullions and rodding structures in the Moine Series of Scotland. Proceedings of the Geologists' Association, 64, 118-151.

WRIGHT D.T. \& KNIGHT I. (1995) -A revised chronostratigraphy for the lower Durness group. Scottish Journal of Geology, 31, 11-22. 